\title{
INDYWIDUALIZACJA W ZINTEGROWANEJ EDUKACJI WCZESNOSZKOLNEJ - MIT CZY RZECZYWISTOŚĆ
}

\begin{abstract}
Abstrakt: Naukowcy, którzy badają mózg, twierdzą, że szkoła w swojej obecnej formie nie wspiera naturalnych procesów uczenia się. Uważają też, że współczesna szkoła nie jest miejscem, które umożliwia indywidualny rozwój uczniów. Wielu badaczy utrzymuje, że szkoła powinna być stworzona od nowa. Żeby znaleźć najlepsze rozwiązania, należy najpierw odpowiedzieć na kilka pytań, m.in.: Dlaczego posyłamy dzieci do szkoły? Czego się tam nauczą? Do czego chcemy je przygotować? Czy chcemy, żeby dzieci były kreatywne i umiały myśleć w sposób innowacyjny, czy też wolimy wspierać i nagradzać uczniów, którzy są w stanie przyswajać wiedzę prezentowaną według utartego modelu? Żeby kształcenie dzieci stało się bardziej efektywne, należy wprowadzić indywidualizację kształcenia, która jest ściśle związana z nauczaniem zróżnicowanym. Wnioski zaprezentowane w niniejszym artykule są oparte na obserwacjach pracy szkolnej dzieci uczęszczających do klas I i III szkoły podstawowej.
\end{abstract}

Słowa kluczowe: indywidualizacja, indywidualizacja kształcenia, nauczanie zróżnicowane, neurodydaktyka

\section{WPROWADZENIE}

O konieczności stosowania indywidualizacji w edukacji wczesnoszkolnej nikogo nie trzeba przekonywać. W większości programów nauczania dla tego poziomu kształcenia, i nie tylko, znajdujemy zalecenie różnicowania wymagań wobec uczniów w zależności od ich potrzeb i możliwości rozwojowych. Jest to podstawowy warunek zapewnienia uczniom maksymalnych szans rozwoju osobowości.

Celem artykułu jest skonfrontowanie założeń teoretycznych dotyczących indywidualizacji w edukacji wczesnoszkolnej z praktyką szkolną. Obserwacje poczynione podczas hospitacji zajęć zintegrowanych w klasie I i III skłoniły autorkę do 
pewnych przemyśleń i sformułowania wniosków. Jednym $\mathrm{z}$ aspektów dobrej pracy szkoły jest stosowanie kształcenia zróżnicowanego, które z założenia zakłada stosowanie indywidualizacji w procesie dydaktyczno-wychowawczym. Dobrej pracy - to znaczy takiej, która wyzwala w uczniach twórczą aktywność, uwzględnia potrzeby, zainteresowania, możliwości rozwojowe wychowanków, umożliwia działanie w grupie, czyni naukę fascynującą, dostarcza pozytywnych przeżyć.

\section{WYJAŚNIENIA TERMINOLOGICZNE}

Czesław Kupisiewicz indywidualizacje nauczania rozumie jako „przystosowanie pracy dydaktycznej do możliwości, zainteresowań i potrzeb poznawczych poszczególnych uczniów”. Bierze tu pod uwagę zdolności uczniów, czas potrzebny im na opanowanie poszczególnych przedmiotów lub tematów, a także treści oraz tempo uczenia (Kupisiewicz, Kupisiewicz 2009, s. 65-66).

Według Tadeusza Lewowickiego indywidualizacja kształcenia to „przede wszystkim takie różnicowanie oddziaływań dydaktycznych i wychowawczych, które umożliwi wszystkim dzieciom uzyskanie przewidzianych wiadomości i umiejętności. Dzięki indywidualizacji procesu, metod i innych elementów systemu dydaktycznego uczniowie powinni osiągnąć podobne sprawności i niezbędny dla dalszej nauki zasób wiadomości. Indywidualne oddziaływania mają więc z bardzo zróżnicowanej grupy dzieci uczynić zespół uczniów, który potrafi wspólnie wykonywać określone zadania w procesie kształcenia" (Lewowicki 1977, s. 166).

Ryszard Więckowski uważa natomiast, że indywidualizacja polega na organizowaniu nauczania, które już z założenia uwzględnia zróżnicowanie klasy szkolnej (Więckowski 1973, s. 31).

Zdaniem Heleny Wolny, indywidualizacja jest jedną z zasad nauczania, polegającą na uwzględnianiu przez nauczyciela w toku nauki szkolnej różnic między uczniami będącymi w tym samym wieku. Różnice te dotyczą zdolności, zainteresowań, tempa pracy, sposobów przyswajania wiedzy oraz motywacji do uczenia się (Wolny 1979).

Rozpoznawanie różnic indywidualnych uczniów i uwzględnianie ich w pracy szkolnej nie jest zadaniem łatwym. Krystyna Kuligowska podaje sześć grup różnic ze względu na cele, proces i wyniki kształcenia, a także uzdolnienia i zainteresowania:

- różnice w zasobie wiedzy, umiejętności oraz doświadczeń (widoczne wśród uczniów danej klasy, dotyczące materiału już przyswojonego i nabywania nowego), 
- różnice w przebiegu czynności poznawczych, zwłaszcza w zakresie spostrzegania i myślenia (zróżnicowanie wychowanków ze względu na sprawność intelektualną),

- różnice w zainteresowaniach (Kuligowska 1975, s. 22-24).

Uwzględnić należy także:

- różnice dotyczące tempa i charakteru pracy, motywacji do uczenia się (nietrudno bowiem zauważyć zależność między systematycznością, obowiązkowością, chęcią a efektami uczenia się),

- różnice dotyczące stanu zdrowia, dojrzałości układu nerwowego, które wpływają znacząco na wydajność i tempo uczenia się, na dojrzałość emocjonalną, podporządkowanie się wymaganiom otoczenia,

- różnice $\mathrm{w}$ warunkach środowiskowych, w tym głównie czas pracy i odpoczynku w domu, sposoby motywowania dziecka do uczenia się, zaspokajanie podstawowych potrzeb egzystencjalnych i emocjonalnych.

Stanisław Palka przyjmuje, że indywidualizacja kształcenia występuje wtedy, gdy nauczyciele podejmują próby dostosowania procesu kształcenia do indywidualnych właściwości dzieci. Należą do nich zdolności ogólne (inteligencja), uzdolnienia, zainteresowania, cechy temperamentu, ich zdrowie i odchylenie od normy rozwoju psychofizycznego. Indywidualizacja będzie też mieć miejsce, gdy nauczyciel „próbuje uwzględnić te doświadczenia, postawy, motywacje i nastawienia, które uczeń ukształtował sobie pod wpływem nie zawsze najkorzystniejszych oddziaływań rodzinnych" (Palka 1988, s. 42). W swojej książce Pedagogika w stanie tworzenia pisze: „Indywidualizacja kształcenia, a więc dostosowanie treści, metod, form i środków nauczania, zakresu wymagań, tempa pracy, sposobu kontrolowania i oceniania do indywidualnych cech psychicznych (np. do poziomu inteligencji oraz uzdolnień), uzdolnień fizycznych (np. mikrodeficytów rozwojowych) uczniów, ma być realizowana po to, by dać szansę sukcesu każdemu uczniowi, ponieważ jest ona czynnikiem najsilniej motywującym ucznia do nauki, wiążącym go emocjonalnie z nauczycielem i szkołą i stanowi zachętę do dalszej pracy" (Palka 2003, s. 120).

Obok pojęcia indywidualizacji istnieje w pedagogice termin kształcenie zróżnicowane. W Polsce za prekursora tego typu kształcenia uważa się Ryszarda Więckowskiego (Więckowski 1975). Analizując różne definicje tego pojęcia, zakłada się, że „kształcenie zróżnicowane jest takim sposobem organizacji pracy na lekcji, w którym uczniowie przez większość czasu są zaangażowani w interesujące i wartościowe $\mathrm{z}$ ich punktu widzenia zadania, ujęte w podstawie programowej, dzięki której nauczyciel wytycza zarówno ogólne, jak i szczegółowe cele kształcenia, a uczniowie są świadomi zakresu nowej wiedzy, umiejętności, zdolności i postaw, jakie mają do opanowania [...] Stosuje się zróżnicowanie przede wszystkim 
w zakresie metod, treści, kontroli i oceny, środowiska nauczania oraz form organizacji pracy na lekcji (Grzegorzewska 2009, s. 33).

\section{PROBLEM RÓŻNIC INDYWIDUALNYCH I INDYWIDUALIZACJA W UJĘCIU HISTORYCZNYM}

Przeglądając dzieje nowożytnej myśli pedagogicznej i polityki oświatowej, dostrzec można fazy nasilania się i osłabiania zainteresowań problemem różnic indywidualnych. K. Kuligowska wyróżnia cztery fale wzrostu zainteresowania tą problematyką. Pierwsza przypada na okres Odrodzenia i Reformacji, kiedy to wzrost zainteresowania człowiekiem implikował zainteresowanie różnicami indywidualnymi. Ludwik Vives (1492-1540) podkreślał potrzebę zwracania uwagi na rodzaj uzdolnienia ucznia oraz jego charakter. Wskazywał, że między uczniami występują różnice w zdolności obserwacji, w łączeniu szczegółów w całość, w porównywaniu, w tempie pracy. Postulował on przyjmowanie do szkoły „na próbę” (Wołoszyn 1965, s. 225, 228-231). Podobne stanowisko reprezentował A. Frycz-Modrzewski, który był zwolennikiem doboru uczniów do szkoły według uzdolnień (tamże, s. 293). Rozwój szkolnictwa jezuickiego przyczynił się do odejścia pedagogów od zagadnień uwzględniania w szkole różnic indywidualnych.

Druga fala wzrostu zainteresowań problematyką różnic indywidualnych przypada na przełom XVIII i XIX wieku, na lata poprzedzające rewolucję francuską. Wspomnieć tu należy poglądy J.J. Rosseau, który sprowadzał wychowanie do umożliwienia dziecku swobodnego wzrostu i dojrzewania oraz chronienie tego rozwoju przed zgubnymi wpływami zewnętrznymi. „Chodziło o tak zwane wychowanie negatywne, odrzucające wszystkie środki, zmierzające do urabiania dziecka, do realizowania celów i ideałów narzuconych z zewnątrz" (Kot 1996, s. 19-20). Pod koniec drugiej połowy XIX wieku zaczęły się nasilać ruchy społeczne. W większości państw Europy zaczęly kształtować się systemy powszechnego szkolnictwa elementarnego. „Wprawdzie teoretycy i wybitni praktycy wychowania i w tym czasie zwracali uwagę na sprawy różnic indywidualnych, to jednak panującymi wówczas były poglądy o jednolitości celów, programów i metod kształcenia, o walorach aktywności nauczyciela i posłuszeństwa ucznia" (pedagogika herbartowska) (Kuligowska 1975, s. 14). Pod koniec XIX wieku rozwój nauki, w tym także psychologii, spowodował ogromny wzrost zainteresowania problemami zróżnicowania uczniów. Wspólne dla wszystkich kierunków i prądów pedagogiki XX wieku było przezwyciężenie ciasnych i sztywnych ram formalizmu szkolnego. Można więc mówić o trzeciej fali wzrostu zainteresowania problemami różnic indywidualnych (tamże, s. 15). 
Wiek dwudziesty, nazwany stuleciem dziecka, był czasem tworzenia nowych systemów dydaktycznych, potocznie określanych jako ruch Nowego Wychowania. Jego przedstawiciele zgodnie krytykowali sformalizowaną, bierną szkołę dziewiętnastowieczną. Pojawiły się rozmaite rozwiązania w zakresie różnicowania kształcenia. Miały one bardzo fragmentaryczny charakter. Wszystkie poszukiwania dotyczyły tylko wybranych elementów systemu dydaktycznego - jedne treści, inne metod bądź organizacji nauczania (Lewowicki 1977, s. 58).

Po drugiej wojnie światowej tworzono zręby socjalizmu i świadomie akcentowano kwestie jednolitości szkoły. Dopiero na przełomie lat sześćdziesiątych i siedemdziesiątych nastąpiła czwarta fala wzrostu zainteresowania problemami różnic indywidualnych, szczególnie w krajach socjalistycznych. W instytucjach naukowych prowadzono wówczas badania nad funkcją czynników biologicznych, środowiskowych i pedagogicznych w rozwijaniu uzdolnień i zainteresowań dzieci, w kształtowaniu ich charakteru, nad zagadnieniami selekcji szkolnej (Kuligowska 1975, s. 19). Pojawiły się wówczas liczne publikacje naukowe dotyczące problemu indywidualizacji (Więckowski 1973, 1975; Kuligowska 1975; Lewowicki 1977; Kujawiński 1978; Piasta, Potyrała, Wasylkowska 1982).

Dzisiaj także obserwujemy duże zainteresowanie problemami indywidualizacji w procesie kształcenia. W ramach Programu Operacyjnego Kapitał Ludzki wiele szkół realizowało projekty systemowe pod nazwą Indywidualizacja procesu nauczania i wychowania uczniów klas I-III szkoły podstawowej. Program, którego realizację przewidziano na lata 2010-2013, skierowany był do najmłodszych uczniów; miał umożliwić szkołom sfinansowanie dodatkowych zajęć dla dzieci szczególnie uzdolnionych bądź mających specyficzne trudności w nauce, a także ułatwić zakup specjalistycznego sprzętu i materiałów dydaktycznych. Program zakończył się, a co za tym idzie finansowanie zajęć dodatkowych - i skończyła się również indywidualizacja w tym zakresie. A przecież praca szkoły nad wyrównywaniem szans uczniów to nie tylko zajęcia pozalekcyjne. Jak pisze Dorota Klus-Stańska, „nie chodzi o to, by uczeń przez godzinę pracował na materiale dostosowanym do swoich możliwości, a potem wracał na zajęcia, na których siedzi ciemny jak tabaka w rogu. Ani o to, by ten zdolny mógł się rozwijać raz w tygodniu, żeby przez pozostałe dni pracować poniżej swojego poziomu" (Klus-Stańska 2013, s. 20). Nauczyciele uważają, że indywidualizacja w klasie trzydziestoosobowej i więcej jest niemożliwa. Okazuje się jednak, że dopiero w takim zespole klasowym jest ona konieczna, bo im więcej mamy uczniów, tym trudniej zgromadzić dzieci o „jednakowym poziomie”. „Polski nauczyciel na pytanie, czemu tak rzadko organizuje pracę w małych zespołach, wyjaśnia, że ma zbyt liczne klasy [...] Podczas gdy w większości krajów Europy Zachodniej uczniowie z tej samej klasy w tym samym czasie pracują na kilku różnych poziomach z uwagi na stan swojego zaawansowania, korzystając 
ze zróżnicowanych kart pracy lub różnych podręczników, w Polsce już dwie klasy łączone traktowane są jako dramat organizacyjny” (Klus-Stańska 2013, s. 20). Z czego to wynika? Uważamy, że uczeń uczy się tylko wówczas, gdy nauczyciel go naucza. Nie wierzymy, że może uczyć się i rozwijać pracując nad zadaniami w zespole, $\mathrm{z}$ kolegami, w swoim tempie i na miarę swoich możliwości.

\section{NEUROBIOLOGICZNE PODSTAWY PROCESU UCZENIA SIE}

Nowa dyscyplina naukowa, jaką jest neurodydaktyka, opierając się na badaniach nad mózgiem, stawia sobie za cel tworzenie nowych koncepcji pedagogicznych, a także inicjuje poszukiwanie systemu edukacyjnego przyjaznego mózgowi i lepiej wykorzystującego jego silne strony (Żylińska 2013, s. 14). Wiele wskazuje na to, że stosowane dziś na całym świecie modele edukacyjne nie są środowiskiem umożliwiającym optymalne wykorzystanie indywidualnego potencjału, z jakim dzieci przychodzą do szkół. W kilku punktach przedstawić należy główne założenia neurodydaktyki:

- aktywność rzeźbi mózg,

- te same informacje wplecione w emocjonalny kontekst mogą być dużo lepiej i łatwiej zapamiętane niż typowo podręcznikowe,

- nic tak silnie nie stymuluje rozwoju mózgu, jak kreatywne zajmowanie się wszelkimi rodzajami sztuki; maluchy powinny możliwie dużo śpiewać, tańczyć, lepić, rysowć, malować i przede wszystkim bawić się z innymi dziećmi,

- w edukacji nie ma dróg na skróty,

- mózg każdego ucznia jest inny, ma inną strukturę i na swój własny sposób przetwarza informacje; człowiek może nauczyć się tylko tego, co potrafi przetworzyć,

- nasze mózgi zostały przystosowane do przetwarzania informacji z zewnątrz, wyciągania $z$ nich ogólnych reguł i rozwiązywania $z$ ich pomocą problemów,

- rozwiązywanie typowych zadań w zeszytach ćwiczeń nie wymaga głębokiego przetwarzania informacji, a więc nie prowadzi do ich zapamiętania; najlepsze efekty osiąga się, gdy uczniowie sami tworzą zadania,

- w nowych koncepcjach na pierwszy plan wysuwa się proces, a nie końcowy produkt,

- odejście od zewnętrznego sterowania jest warunkiem rozwinięcia samodzielności uczniów; nauczyciel kierując każdym krokiem swoich podopiecznych, powoduje u nich wyuczoną bezradność, 
- mózgi uczniów bez udziału świadomości wyłapują z otoczenia wszystko to, co nowe, zaskakujące, intrygujące lub przydatne; uwaga uczniów automatycznie zanika, gdy omawiane zagadnienia oceniane zostają przez układ limbiczny jako mało istotne, niewnoszące niczego nowego i niewymagające wyjaśnień,

- kluczowym momentem jest początek lekcji; to wtedy układ limbiczny każdego ucznia podejmuje decyzję o uwalnianiu neuroprzekaźników i zainicjowaniu procesu uczenia się,

- nauczyciel powinien zastanowić się, które informacje są rzeczywiście ważne,

- motywacja jest pochodną ciekawości i zainteresowań uczniów,

- presja wywierana na dzieci hamuje ich rozwój,

- zachwyt światem ułatwia uczenie się dzieci; szkoda, że tak rzadko wykorzystują go autorzy podręczników i materiałów dydaktycznych,

- im więcej różnorodnych, pozytywnych bodźców, im bogatsze środowisko, w którym żyje dziecko, tym lepsze warunki dla rozwoju sieci neuronalnej,

- zadaniem szkoły nie powinno być wymuszanie rozwoju wszystkich uczniów w jednym, z góry określonym tempie, ale stworzenie wszystkim optymalnych warunków indywidualnego rozwoju,

- mechaniczne wykonywanie zadań, w które uczniowie nie angażują się emocjonalnie i które nie sprawiają im żadnej przyjemności, nie inicjuje procesu efektywnej nauki,

- mózg to organ społeczny, którego rozwój wymaga interakcji z innymi ludźmi,

- przeżycia łączące się z silnymi emocjami zostają trwale zachowane w strukturach pamięci i mają wpływ nie tylko na motywację do nauki i nastawienie do szkoły, ale również na poczucie zaufania i bezpieczeństwa,

- aby nauka była efektywna, powinna być aktem woli, a nie przymusu,

- potrzeba ruchu, aktywność i dążenie do autonomicznych, kreatywnych działań nie jest u dzieci przejawem zaburzeń, ale naturalną formą funkcjonowania i uczenia się (tamże).

Głównym zarzutem stawianym współczesnym nauczycielom jest to, że ich sposób pracy z uczniem nie sprzyja rozwojowi myślenia, że przekazują wiedzę w sposób akademicki, że „realizują program”, nie zwracając uwagi na dzieci. Jak udowodniono licznymi badaniami nad funkcjonowaniem mózgu, nikomu nie można przekazać gotowej wiedzy. Nauka wymaga aktywności, doświadczania, samodzielnego odkrywania, przeżywania, aby informacje, jakie uczeń uzyskuje z różnych źródeł (nauczyciel, podręczniki, encyklopedie, filmy dydaktyczne, wycieczki 
edukacyjne itp.), zostały przetworzone i dołączone do jego dotychczasowej wiedzy. Uczeń sam buduje wiedzę, dołączając do tego, co już wie na dany temat, nowe informacje. To, że dzieci najlepiej i najefektywniej uczą się w grupie, rozwiązując problemy dostosowane do ich możliwości, nie jest wielkim odkryciem. Dlaczego więc tak rzadko możemy w szkole spotkać tę formę organizacyjną zajęć? Okazuje się również, że większe korzyści „naukowe” odnosi dziecko pisząc ściągi, niż wykonując niezliczone ilości ćwiczeń w kartach pracy. Dobra ściąga wymaga przemyślenia, uporządkowania wiedzy, streszczenia pewnych myśli - powoduje więc, że zawarty w niej materiał uczeń „przepracował”. Zapominamy również, że każdy człowiek do pracy potrzebuje określonych warunków, przede wszystkim spokoju, przyjaznej atmosfery. Dla każdego nowe zadanie jest sytuacją trudną, a co za tym idzie - sytuacją stresową. Ucznia rozlicza się za efekty, nie zaś za wysiłek i starania. Nie zawsze wyniki są dla nauczycieli zadowalające, ale zapominamy, że zaangażowanie i dobre chęci dziecka, poczucie własnej wartości są niejednokrotnie cenniejsze.

\section{INDYWIDUALIZACJA PROCESU KSZTAŁCENIA I WYCHOWANIA - WNIOSKI Z OBSERWACJI ZAJĘĆ ZINTEGROWANYCH}

Indywidualna praca z uczniem na zajęciach zintegrowanych wymaga dostosowania treści, metod, form organizacyjnych, zasad kształcenia, sposobów kontroli i oceny oraz środków dydaktycznych do indywidualnych zdolności, umiejętności i zainteresowań uczniów. Każdemu dziecku należy zapewnić:

- ciekawą ofertę edukacyjno-wychowawczo-profilaktyczną zgodną z jego indywidualnymi potrzebami i możliwościami edukacyjno-rozwojowymi,

- motywację do pracy, możliwość działania, odkrywania, przeżywania (praca metodami aktywizującymi, nauczanie-uczenie się problemowe),

- życzliwą atmosferę w klasie, w której będzie czuło się pewnie, będzie miało prawo do niewiedzy, błędów, zadawania pytań, odnoszenia sukcesów,

- obcowanie z nauczycielem współpartnerem w rozwiązywaniu ciekawych zadań problemowych (nauczyciel - inicjator, partner, życzliwy doradca, kreator, fachowiec).

Pamiętać należy, że indywidualizacja w nauczaniu i wychowaniu stanowi zasadę, czyli normę postępowania dydaktycznego. Jest więc obowiązkiem każdego nauczyciela edukacji wczesnoszkolnej, który pracuje z dziećmi na różnym poziomie rozwoju umysłowego, emocjonalnego, społecznego, moralnego, o różnych zdolnościach i talentach, ale również z dziećmi zaburzonymi, „dysfunkcyjnymi”. Podstawą dobrej pracy z uczniem jest znajomość jego mocnych i słabych stron. Bardzo 
ważne są więc kompetencje diagnostyczne i terapeutyczne nauczycieli klas początkowych. Od ich wiedzy i umiejętności zależą losy dzieci, to, czy potrafią im pomóc, wesprzeć je w pokonywaniu trudnych sytuacji, ustrzec przed niepowodzeniami w nauce i w życiu.

Doniesienia $\mathrm{z}$ badań nad funkcjonowaniem mózgu i wnioski, jakie z nich wynikają, powinny być dla nauczycieli wytycznymi do zmiany sposobu nauczania. Zastanówmy się więc, jakie warunki muszą być spełnione, aby efektywność pracy nauczycieli i uczniów była jak największa? A. Gardner podaje warunki skutecznej pracy dydaktycznej i wychowawczej:

- Bardzo ważna jest na pewno znajomość przez uczniów celów i zadań zajęć, zarówno celów nauczycielskich, jak i uczniowskich (autorka poleca koncepcję Oceniania Kształtujacego Danuty Sterny) (Sterna 2008, 2014).

- Jasne kryteria oceniania pracy wychowanków, ustalone wspólnie z nauczycielem, spowodują, że rzetelnie oceniać będziemy przede wszystkim zaangażowanie, kreatywność dzieci, a niekoniecznie efekty.

- Najważniejszą częścią zajęć, według neurodydaktyków, jest ich początek, stworzenie takiej sytuacji wyjściowej (początkowej), która zaintryguje uczniów i zmotywuje ich do wytężonej pracy.

- Dominującą formą organizacji pracy uczniów powinna być praca w grypach (parach); najszybciej uczymy się ucząc innych.

- Nauczmy dzieci uczenia się, pracy metodami aktywizującymi, które pozwalają wszechstronnie przetwarzać, przeżywać, doświadczać nowe informacje. Wymagamy od młodych ludzi kreatywności, ale nie kształcimy jej u uczniów.

- Pamiętajmy, że podręcznik, karty pracy to środki dydaktyczne (możemy z nich korzystać, ale nie musimy). Najbardziej wskazane jest tworzenie przez dzieci swoich pomocy, w zależności od preferowanego sposobu uczenia się (Adamek, Bałachowicz 2013). Wykonanie wszystkich ćwiczeń w podręcznikach i ćwiczeniach nie świadczy o tym, że uczeń rozumie, umie. Niektóre teksty w podręcznikach są dla dzieci nieciekawe (mowa tu chociażby o tzw. czytankach), niekiedy wręcz infantylne - zastąpmy je innymi, ciekawszymi, korespondującymi z zainteresowaniami dzieci (mogą to być także teksty uczniowskie).

- Systematyczne stosowanie indywidualizacji na zajęciach w klasach początkowych jest obowiązkiem każdego nauczyciela.

- Diagnoza uczniów pod kątem gotowości szkolnej powinna uwzględniać także rozpoznanie typów inteligencji oraz stylów uczenia się uczniów (Gardner 2009). 
Nie będzie tutaj krytyki zajęć obserwowanych przez autorkę, chociaż zabrakło na nich właściwie wszystkich wymienionych wyżej elementów. Na rynku wydawniczym pojawiło się w ostatnich latach wiele ciekawych opracowań dotyczących efektywnej pracy szkolnej. Krytyczny nauczyciel na pewno po nie sięgnie.

\section{LITERATURA}

Adamek I., Bałachowicz J. (2013). Kompetencje kreatywne nauczycieli wczesnej edukacji dziecka. Wydawnictwo Impuls, Kraków.

Dryden G., Vos J. (1999). Rewolucja w uczeniu. Zysk i S-ka, Kraków.

Gardner H. (2009). Inteligencje wielorakie. Nowe horyzonty w teorii i praktyce. Wydawnictwo Laurum, Warszawa.

Grzegorzewska S. (2009). Różnicowanie kształcenia w klasach początkowych. Wydawnictwo Impuls, Kraków.

Klus-Stańska D. (2013). Szkoła dla dziecka czy dziecko dla szkoły, czyli garść uwag o gotowości szkolnej. „Dysleksja” 2.

Kot S. (1996). Historia wychowania. T. II. Wydawnictwo PWN, Warszawa.

Kujawiński J. (1978). Indywidualizacja w problemowym nauczaniu uspołeczniajacym w szkole podstawowej. Wydawnictwo Instytutu Kształcenia Nauczycieli i Badań Oświatowych, Poznań.

Kuligowska K. (1975). Problemy indywidualizacji nauczania. WSiP, Warszawa.

Kupisiewicz Cz., Kupisiewicz M. (2009). Słownik pedagogiczny. Wydawnictwo PWN, Warszawa.

Lewowicki T. (1977). Indywidualizacja kształcenia. Dydaktyka różnicowa. Wydawnictwo PWN, Warszawa.

Palka S. (1988). Pedagogiczne czynniki różnicujące szanse edukacyjne uczniów. W: H. Moroz (red.). Czynniki różnicujące szanse edukacyjne dzieci w młodszym wieku szkolnym. Wydawnictwo Uniwersytetu Śląskiego, Katowice.

Palka S. (2003). Pedagogika w stanie tworzenia. Kontynuacje. Wydawnictwo Uniwersytetu Jagiellońskiego, Kraków.

Piasta W., Potyrała P., Wasylkowska K. (1982). Różnicowanie kształcenia wczesnoszkolnego. Wydawnictwo Uniwersytetu Wrocławskiego, Wrocław.

Rose C., Nichol M.J. (2009). Ucz się szybciej, na miarę XXI wieku. Wydawnictwo Logos, Warszawa.

Sterna D. (2008). Ocenianie kształtujące w praktyce. Wydawnictwo Civitas, Warszawa.

Sterna D. (2014). Uczę (się) w szkole. Wydawnictwo Centrum Edukacji Obywatelskiej, Warszawa. 
Więckowski R. (1973). Problem indywidualizacji w nauczaniu. Zakład Narodowy Imienia Ossolińskich, Wrocław-Warszawa-Kraków-Gdańsk.

Więckowski R. (1975). Nauczanie zróżnicowane. Nasza Księgarnia, Warszawa.

Wolny H. (1979). Zasada indywidualizacji w nauczaniu języka polskiego. WSiP, Warszawa.

Wołoszyn S. (wybór i oprac.) (1965). Źródła do dziejów i myśli pedagogicznej. T.I. Wydawnictwo PWN, Warszawa.

Żylińska M. (2013). Neurodydaktyka. Nauczanie i uczenie się przyjazne mózgowi. Wydawnictwo Naukowe Uniwersytetu Mikołaja Kopernika, Toruń.

\begin{abstract}
The brain researchers persuade that school in its present form does not support natural process of learning and it is not the place where the individual development of every student is enabled. A lot of scientists claim that school ought to be re-invented again but at first we need to know why we send children to school, what they are going to learn there, what we want them to be prepared for. Do we want to prepare children to be creative and innovatively thinking creators or maybe we prefer supporting and awarding those students who are able to follow well-known patterns? Applying individualization in the didactic process is one of the conditions of effective teaching. This individualization is closely connected to varied education. This article presents conclusions based on the observations of integrated lessons of primary education in grade 1 and grade 3 .
\end{abstract}

Key words: individualization, individual differences, varied education, neurodidactics 